\title{
ANALISIS KURVA ROC PADA MODEL LOGIT DALAM PEMODELAN DETERMINAN LANSIA BEKERJA DI KAWASAN TIMUR INDONESIA*
}

\author{
Muhammad Rizqi Fachrian Nur ${ }^{1}$ and Siskarossa Ika Oktora ${ }^{2}$
}

\author{
${ }^{1}$ Politeknik Statistika STIS, Indonesia,15.8765@stis.ac.id \\ 2Politeknik Statistika STIS, Indonesia, siskarossa@stis.ac.id
}

\begin{abstract}
Indonesian Journal of Statistics and Its Applications (eISSN:2599-0802)
Vol 4 No 1 (2020), 116 - 135
\end{abstract}

Copyright (C) 2020 Muhammad Rizqi Fachrian Nur and Siskarossa lka Oktora. This is an open-access article distributed under the Creative Commons Attribution License, which permits unrestricted use, distribution, and reproduction in any medium, provided the original work is properly cited.

\begin{abstract}
Binary logistic regression is used for probability modeling or to predict binary response variables (Success / Failure) from one or more explanatory variables that are continuous or categorical. In carrying out this analysis, there are several ways to test the suitability of the resulting model, and one of them is the area under the ROC curve. The application of the analysis method in this study is the determinant of the elderly population to work. The population of the elderly in Indonesia is increasing every year. Many view that the elderly depend on other residents, especially in terms of the economy. However, if seen from the percentage of elderly working in Indonesia, it is increasing, including the elderly in KTI. The purpose of this study is to determine the characteristics of the elderly in $\mathrm{KTI}$, know the factors that influence the decision of the elderly population to work in $\mathrm{KTI}$ and find out the tendency of variables that affect the decision of the elderly to work in KTI. The data used are raw data from Badan Pusat Statistik (BPS) was Survei Sosial Ekonomi Nasional (Susenas) Kor March 2018. This study using descriptive analysis methods and binary logistic regression. The results are that the variables that significantly influence the decisions of the elderly to work are residence, gender, age, education, family status, marital status, health complaints, and health insurance. Elderly who has characteristics residing in rural, male sex, classified as young elderly (60-69 years old), has the highest level of elementary school education, has the status of KRT in his family, is married, has no complaints health, and not having health insurance will have a greater tendency to decide to work.
\end{abstract}

Keywords: elderly worker, binary logistic regression, ROC curve.

*Received Aug 2019; Accepted Feb 2020; Published online on Feb 2020 


\section{Pendahuluan}

Transisi demografi yang terjadi di Indonesia saat ini adalah meningkatnya jumlah penduduk lansia akibat terjadinya baby boom (ledakan kelahiran) pada tahun 19501970. Berdasarkan hasil proyeksi Sensus Penduduk 2010 persentase lansia Indonesia pada tahun 2035 akan mencapai 15 persen, angka ini hampir mencapai dua kali lipat jika dibandingkan dengan jumlah lansia Indonesia pada tahun 2017 yakni 23,4 juta atau 8,97 persen (BPS, 2018a).

Peningkatan jumlah lansia di Indonesia dipengaruhi oleh peningkatan Angka Harapan Hidup (AHH) Indonesia. Sejak tahun 2010 sampai 2017 AHH Indonesia selalu mengalami peningkatan, dan tercatat AHH Indonesia tahun 2017 sebesar 71,06 tahun (BPS, 2018a). Lansia merupakan seseorang yang mulai memasuki usia 60 tahun ke atas (WHO, 2002). Hal ini sesuai juga dengan definisi lansia menurut Undang-Undang No. 13 tahun 1998 tentang Kesejahteraan Lansia (Pemerintah RI, 1998)dan BPS yang mendefinisikan lansia sebagai orang yang telah berusia 60 tahun ke atas. Dengan meningkatnya jumlah lansia setiap tahunnya, secara otomatis akan meningkatkan juga jumlah rumah tangga yang dihuni oleh lansia. Berdasarkan hasil Survei Sosial Ekonomi Nasional (SUSENAS) 2017, selama empat tahun terakhir rumah tangga lansia mengalami peningkatan dari 24,5 persen menjadi 26,35 persen dengan 60 persen diantaranya menjadikan lansia sebagai kepala rumah tangga. Hampir setengah rumah tangga lansia di Indonesia tergolong ke dalam status ekonomi rumah tangga 40 persen ekonomi terendah yaitu sebesar 43,18 persen, sedangkan rumah tangga lansia di Indonesia tergolong ke dalam status ekonomi rumah tangga 40 persen ekonomi menengah sebesar 36,6 persen dan rumah tangga lansia yang tergolong ke dalam status ekonomi rumah tangga 20 persen ekonomi tinggi hanya sebesar 20,22 persen.

Hal ini mengindikasikan taraf ekonomi penduduk lansia sangatlah memprihatinkan dan memaksa lansia untuk tetap bekerja. Salah satu faktor yang menyebabkan masih banyaknya lansia terutama yang memiliki fisik dan mental yang cukup baik untuk bekerja adalah kebutuhan ekonomi yang tinggi. Salah satunya dikarenakan tidak/belum adanya jaminan sosial ekonomi yang memadai bagi seseorang lansia di hari tuanya. Berdasarkan hasil SUSENAS 2017 persentase ini mengalami kenaikan menjadi 47,92 persen pada tahun 2017. Kementerian Kesehatan dan Kementerian Ketenagakerjaan menyebutkan bahwa tingginya persentase lansia yang bekerja juga dapat menggambarkan rendahnya kesejahteraan lansia. Sementara Tujuan Pembangunan Berkelanjutan (TPB) nomor 3 adalah meningkatkan kesejahteraan seluruh penduduk semua usia termasuk lansia.

Rencana Pembangunan Jangka Menengah Nasional (RPJMN) 2015-2019 membagi wilayah Indonesia menjadi dua bagian, yaitu Kawasan Timur Indonesia (KTI) yang mencakup wilayah Kalimantan, Sulawesi, Nusa Tenggara, Papua dan Maluku sedangkan sisanya Kawasan Barat Indonesia (KBI).

Pada Tabel 1 dapat diketahui bahwa jumlah wilayah dari persentase lansia bekerja di Kawasan Timur Indonesia (KTI) lebih dominan berada di atas rata-rata nasional dari tahun 2014-2016 meskipun pada tahun 2017 tidak terdapat perbedaan dengan KBI. Persentase lansia bekerja di Kawasan Timur Indonesia (KTI) dari tahun 20142017 pada umumnya mengalami peningkatan dan lansia bekerja di KTI pada tahun 2017 mencapai 46,55 persen (BPS, 2018a). Hal ini mengindikasikan bahwa hampir 
separuh lansia di KTI masih bekerja untuk memenuhi kebutuhan hidupnya. Ada banyak faktor yang memengaruhi tingginya angka lansia yang bekerja di KTI, baik dari aspek sosial maupun ekonomi.

Tabel 1: Jumlah wilayah di Kawasan Timur Indonesia (KTI) dan Kawasan Barat Indonesia (KBI) yang berada di atas rata-rata nasional tahun 2014-2017.

\begin{tabular}{ccccc}
\hline Wilayah & 2014 & 2015 & 2016 & 2017 \\
\hline Kawasan Timur Indonesia (KTI) & 10 & 11 & 14 & 9 \\
Kawasan Barat Indonesia (KBI) & 8 & 8 & 8 & 9
\end{tabular}

Sumber: (BPS, 2015, 2016, 2017, 2018a, 2018b)

Penerapan analisis regresi logistik biner biasanya digunakan dalam penelitian sosial dan salah satunya adalah penelitian untuk mengetahui faktor-faktor apa saja yang memengaruhi lansia untuk bekerja. Metode yang biasa digunakan untuk mengestimasi parameter dalam model regresi logistik adalah Maximum Likelihood. Metode tersebut menghasilkan nilai parameter dengan cara memaksimalkan fungsi likelihood dari nilai peluang pada kumpulan data observasi. Fungsi tersebut menyatakan peluang dari data observasi sebagai sebuah fungsi dari parameter yang belum diketahui (Hosmer \& Lemeshow, 2000). Setelah melakukan estimasi parameter pada model, selanjutnya perlu dilakukan pengujian signifikansi variabel dalam model. Pengujian signifikansi parameter ini terdiri atas dua uji, yaitu uji simultan dan uji parsial.

Model yang dihasilkan perlu dilakukan pengujian kesesuaian model untuk mengetahui apakah model yang terbentuk sudah sesuai dalam menjelaskan hubungan antara variabel respon dan variabel penjelas. Hosmer \& Lemeshow (2000) menyatakan terdapat beberapa uji kesesuaian model yaitu pearson chi-square test, hosmer-lemeshow test, tabel klasifikasi, luas area di bawah kurva Receiving Operating Curve (ROC) dan ukuran lainnya. Dalam penelitian ini akan digunakan uji kesesuaian model dengan menggunakan kurva ROC. Pada umumnya, kurva ROC jarang digunakan dalam penelitian uji kesesuaian model. Berdasarkan Agresti (2000) disebutkan bahwa kurva ROC lebih informatif jika dibandingkan dengan tabel klasifikasi, karena kurva ROC memberikan hasil prediksi seluruh cut-off yang mungkin terjadi. Setelah didapatkan model yang sesuai, selanjutnya dilakukan interpretasi odds ratio (rasio kecenderungan) dari koefisien hasil estimasi model tersebut untuk mengetahui tingkat risiko dari masing-masing variabel penjelas.

Berdasarkan penjabaran tersebut, tujuan pertama dari penelitian ini adalah untuk menguraikan gambaran umum karakteristik lansia di KTI. Kedua, menguji faktorfaktor yang memengaruhi keputusan penduduk lansia untuk bekerja di Kawasan Timur Indonesia dengan pendekatan regresi logistik biner. Tujuan ketiga adalah untuk menganalisis ukuran kebaikan model melalui kurva ROC. Dan tujuan terakhir adalah untuk mengetahui kecenderungan faktor-faktor yang memengaruhi keputusan penduduk lansia untuk bekerja di Kawasan Timur Indonesia. 


\section{Metodologi}

\subsection{Tinjauan Pustaka}

Analisis regresi adalah salah satu metode yang digunakan untuk mengetahui hubungan antara variabel respon dengan satu atau lebih variabel penjelas. Regresi logistik merupakan metode yang digunakan untuk menganalisis hubungan antara satu variabel respon dan satu atau beberapa variabel penjelas, dimana variabel responnya bersifat diskrit. Yang membedakan antara model regresi logistik dengan model regresi linier adalah variabel respon dalam regresi logistik bersifat biner atau dikotomi (Hosmer \& Lemeshow, 2000). Sementara berdasarkan Azen \& Walker (2011), analisis regresi logistik biner digunakan untuk pemodelan probabilitas atau untuk memprediksi variabel respon biner (Ya/Tidak atau Sukses/Gagal) dari satu atau lebih variabel penjelas yang bersifat kontinu atau kategorik. Model regresi logistik biner digunakan jika variabel responnya menghasilkan dua kategori yang bernilai 0 dan 1, dimana $Y=1$ merupakan pernyataan kejadian "ya/sukses" dan $Y=0$ menyatakan "tidak/gagal" (Hosmer \& Lemeshow, 2000). Bentuk umum dari regresi logistik biner adalah sebagai berikut:

$$
\pi(x)=\frac{\exp \left(\beta_{0}+\beta_{1} x_{1}+\cdots+\beta_{p} x_{p}\right)}{1+\exp \left(\beta_{0}+\beta_{1} x_{1}+\cdots+\beta_{p} x_{p}\right)}
$$

dimana, $\pi(x)$ : peluang kejadian sukses $(\mathrm{Y}=1), 0 \leq \pi(x) \leq 1$

Dari persamaan di atas, $p$ merupakan jumlah variabel penjelas yang digunakan dalam model. Fungsi $\pi(x)$ merupakan fungsi nonlinier, sehingga perlu dilakukan transformasi ke dalam bentuk linier agar dapat melihat hubungan antara variabel penjelas dan variabel respon. Transformasi $\pi(\mathrm{x})$ adalah logit transformation atau log odds (Hosmer \& Lemeshow, 2000). Odds dapat didefinisikan dengan formula berikut:

$$
\frac{\pi(x)}{1-\pi(x)}=\exp \left(\beta_{0}+\beta_{1} x_{1}+\cdots+\beta_{p} x_{p}\right)
$$

Sehingga transformasi logit sekaligus model umum regresi logistik biner dengan $\mathrm{p}$ variabel penjelas dapat ditulis sebagai berikut:

$$
g(x)=\ln \left(\frac{\pi(x)}{1-\pi(x)}\right)=\beta_{0}+\beta_{1} x_{1}+\cdots+\beta_{p} x_{p}
$$

Pada model di atas, $\pi(x)$ adalah peluang "ya/sukses" atau peluang $\mathrm{Y}=1, \beta_{0}$ merupakan parameter intersep, dan $\beta_{j}$ merupakan koefisien yang berhubungan dengan variabel penjelas ke-j $\left(x_{j}\right)$. Variabel penjelas dapat berupa variabel kontinyu atau variabel kategorik. Dalam menggunakan variabel kategorik perlu dibuat sebanyak C-1 indikator yang sering disebut sebagai dummy coding.

Terkait dengan penggunaan variabel-variabel dalam penelitian ini maka dapat disimpulkan berdasarkan beberapa hasil penelitian sebelumnya. Hasil penelitian Reddy (2016) menyimpulkan bahwa jenis kelamin, usia, pendidikan, tempat tinggal, pendapatan perkapita, dan keanggotaan kelompok sosial berpengaruh secara signifikan terhadap keputusan lansia untuk bekerja atau tidak. Selain itu, Sumarsono (2015) menemukan bahwa umur, pendidikan, pengeluaran rumah tangga, jenis kelamin, kondisi kesehatan, status kawin, status dalam rumah tangga, dan daerah tempat tinggal memengaruhi status bekerja lansia.

\subsection{Metode Pengumpulan Data}

Dalam penelitian ini data yang digunakan adalah data sekunder yang berasal dari raw data SUSENAS Kor Maret 2018 yang dilakukan oleh BPS. SUSENAS merupakan kegiatan survei yang dilakukan untuk mengumpulkan data yang berkaitan dengan 
kondisi sosial ekonomi masyarakat di Indonesia. Lokus penelitian ini mencakup 17 provinsi di Kawasan Timur Indonesia. Unit analisis dalam penelitian ini adalah penduduk lansia yang didefinisikan sebagai penduduk yang berusia 60 tahun ke atas. Total sampel dalam penelitian ini adalah 33.636 lansia.

Terdapat dua variabel yang diteliti dalam penelitian ini yaitu variabel dependen dan variabel penjelas. Keputusan lansia dalam memilih untuk bekerja (bekerja atau tidak bekerja) merupakan variabel dependen dalam penelitian ini. Definisi lansia bekerja adalah lansia yang melakukan pekerjaan dengan maksud memperoleh atau membantu memperoleh penghasilan atau keuntungan paling sedikit selama satu jam dalam seminggu yang lalu dan seseorang lansia yang punya pekerjaan tetapi dalam seminggu yang lalu sementara tidak bekerja. Variabel yang digunakan dalam penelitian ini, tersaji pada Tabel 2 berikut.

Tabel 2: Variabel penelitian.

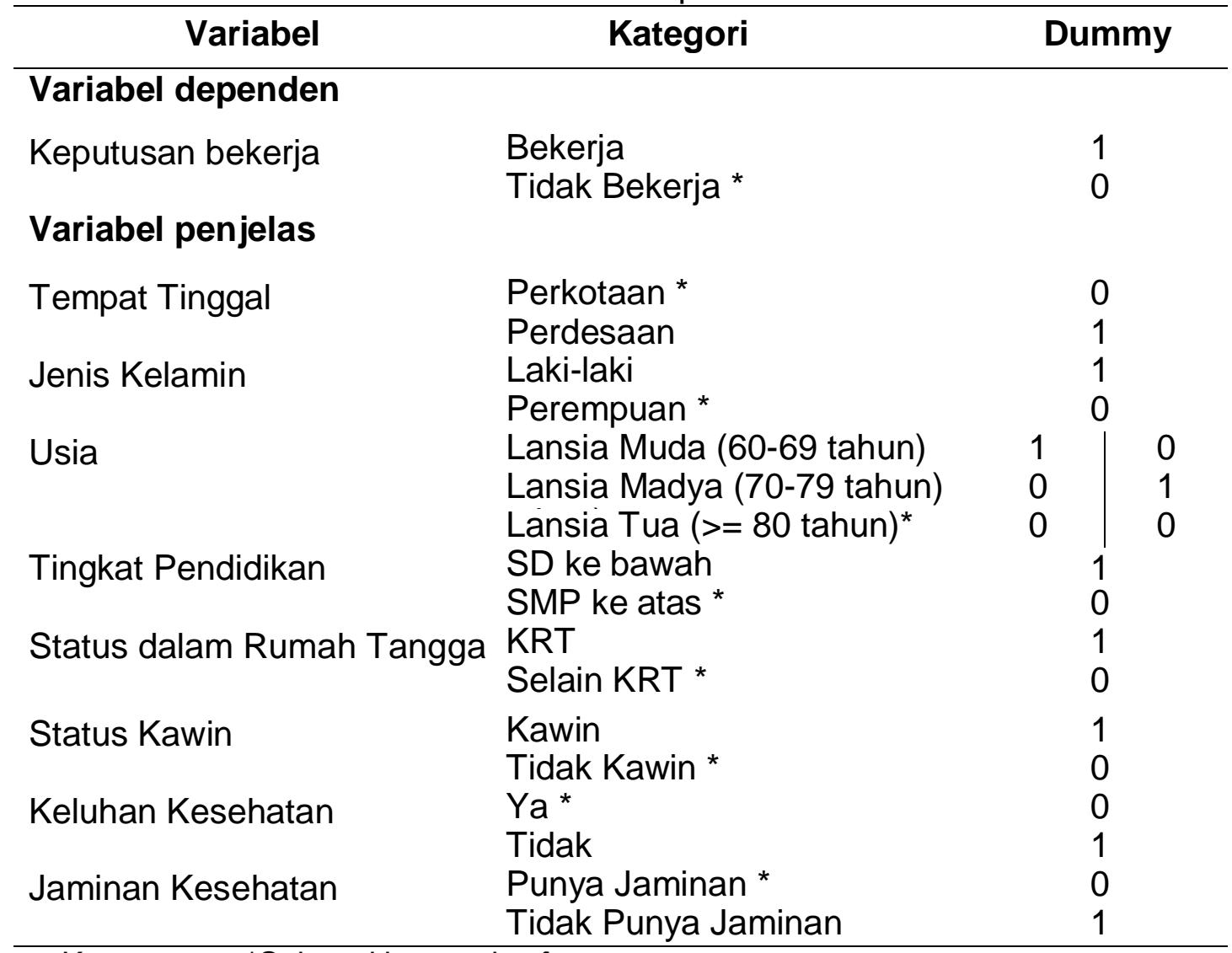

Keterangan: *Sebagai kategori reference

\subsection{Metode Analisis}

Dalam penelitian ini, metode analisis yang akan digunakan terbagi ke dalam dua metode yaitu metode analisis deskriptif dan metode analisis inferensia.

\section{Analisis Deskriptif}

Analisis deskriptif merupakan analisis statistik yang berkaitan dengan pengumpulan dan penyajian suatu gugus data sehingga memberikan informasi yang dapat berguna. Dalam penelitian ini, analisis deskriptif digunakan untuk memberikan gambaran umum tentang karakteristik lansia di Kawasan Timur Indonesia. Selain itu juga digunakan untuk memberikan gambaran umum tentang lansia bekerja dengan faktor-faktor yang 
memengaruhinya di Kawasan Timur Indonesia. Hasil analisis deskriptif akan disajikan dalam bentuk tabel dan grafik.

\section{Analisis Inferensia}

Dalam penelitian ini analisis inferensia yang digunakan adalah analisis regresi logistik biner yang digunakan untuk mengetahui pengaruh variabel penjelas terhadap variabel respon (keputusan lansia memilih untuk bekerja), dan mengetahui kecenderungan keputusan lansia memilih untuk bekerja berdasarkan kategori pada variabel penjelas yang terdiri dari delapan variabel. Berdasarkan model umum regresi logistik biner, model regresi logistik biner pada penelitian ini adalah sebagai berikut:

$$
\begin{aligned}
g(x)=\beta_{0}+ & \beta_{1} \text { TempatTinggal }+\beta_{2} \text { JenisKelamin }+\beta_{3} \text { Usia } 1+\beta_{4} \text { Usia } 2 \\
& +\beta_{5} \text { Pendidikan }+\beta_{6} \text { StatusRT }+\beta_{7} \text { StatusKawin } \\
& +\beta_{8} \text { KeluhanKesehatan }+\beta_{9} \text { JaminanKesehatan }
\end{aligned}
$$

Keterangan:

$\begin{array}{ll}\beta_{0}, \beta_{1}, \ldots, \beta_{9} & : \text { koefisien regresi logistik biner } \\ \text { TempatTinggal } & : \text { dummy tempat tinggal } \\ \text { JenisKelamin } & : \text { dummy jenis kelamin } \\ \text { Usia1 } & : \text { dummy usia lansia muda (60-69 tahun) } \\ \text { Usia2 } & : \text { dummy usia lansia madya (70-79 tahun) } \\ \text { Pendidikan } & : \text { dummy pendidikan1 } \\ \text { StatusRT } & : \text { dummy status dalam rumah tangga } \\ \text { StatusKawin } & : \text { dummy status perkawinan } \\ \text { KeluhanKesehatan } & : \text { dummy keluhan kesehatan } \\ \text { JaminanKesehatan } & : \text { dummy jaminan kesehatan. }\end{array}$

Tahapan analisis regresi logistik biner adalah sebagai berikut:

1. Pendugaan parameter

Metode yang biasa digunakan untuk mengestimasi parameter dalam model regresi logistik adalah Maximum Likelihood. Metode tersebut menghasilkan nilai parameter dengan cara memaksimumkan fungsi likelihood dari nilai peluang pada kumpulan data observasi. Fungsi tersebut menyatakan peluang dari data observasi sebagai sebuah fungsi dari parameter yang belum diketahui (Hosmer \& Lemeshow, 2000).

Pada model regresi logistik biner, $Y$ dikategorikan sebagai 0 dan 1 , maka $\pi(x)$ memberikan peluang bersyarat bahwa $Y$ bernilai 1 dengan syarat $x$, yang dapat dinotasikan $P(Y=1 \mid x)$. Sementara $1-\pi(x)$ memberikan peluang bersyarat bahwa $Y$ bernilai 0 dengan syarat $\mathrm{x}$, yang dapat dinotasikan $P(Y=0 \mid x)$. Ketika $y_{i}=1$, maka kontribusi fungsi likelihood terhadap pasangan $\left(x_{i} y_{i}\right)$ adalah $\pi\left(x_{i}\right)$. Sementara ketika $y_{i}=0$, maka kontribusi fungsi likelihood terhadap pasangan $\left(x_{i} y_{i}\right)$ adalah $1-\pi\left(x_{i}\right)$. Sehingga dapat dituliskan persamaan kontribusi fungsi likelihood terhadap pasangan $\left(x_{i} y_{i}\right)$ adalah sebagai berikut:

$$
f\left(y_{i}, \pi\left(x_{i}\right)\right)=\left[\pi\left(x_{i}\right)\right]^{y_{i}}\left[1-\pi\left(x_{i}\right)\right]^{1-y_{i}}
$$

Seperti pada kasus regresi logistik biner dengan satu variabel independen, data observasi diasumsikan saling bebas atau independen, sehingga fungsi likelihood dapat dirumuskan sebagai berikut: 


$$
\begin{aligned}
l(\beta) & =\prod_{\substack{i=1 \\
n}}^{n} f\left(y_{i}, \pi\left(x_{i}\right)\right) \\
& =\prod_{i=1}^{n}\left[\pi\left(x_{i}\right)\right]^{y_{i}}\left[1-\pi\left(x_{i}\right)\right]^{1-y_{i}}
\end{aligned}
$$

Dan akan lebih mudah jika menggunakan logaritma natural atau log dari persamaan di atas. Dengan demikian, loglikelihood dapat didefinisikan sebagai berikut:

$$
\begin{aligned}
L(\beta) & =\ln _{n}[l(\beta)] \\
& =\sum_{i=1}^{n} y_{i}\left(\beta_{0}+\sum_{j=i}^{p} \beta_{j} x_{i j}\right)-\sum_{i=1}^{n} \ln \left[1+\exp \left(\beta_{0}+\sum_{j=i}^{p} \beta_{j} x_{i j}\right)\right]
\end{aligned}
$$

Keterangan:

$$
\begin{aligned}
& i: 1,2, \ldots, n \\
& j: 1,2, \ldots, p \\
& n: \text { banyaknya observasi } \\
& p \text { : banyaknya variabel }
\end{aligned}
$$

Estimasi parameter $\beta$ diperoleh dengan cara memaksimalkan/memaksimumkan $L(\beta)$ yaitu dengan melakukan diferensiasi $L(\beta)$ terhadap $\beta_{0}$ dan $\beta_{j}$ dengan hasil persamaannya sama dengan nol, sehingga nantinya menghasilkan persamaan yang disebut sebagai persamaan likelihood. Persamaan tersebut dapat dituliskan sebagai berikut:

dan

$$
\frac{\partial(L(\beta))}{\partial \beta_{0}}=\sum_{i=1}^{n}\left[y_{i}-\pi\left(x_{i}\right)\right]=0
$$

Keterangan: $j: 1,2, \ldots, p$

$$
\frac{\partial(L(\beta))}{\partial \beta_{j}}=\sum_{i=1}^{n} x_{i j}\left[y_{i}-\pi\left(x_{i}\right)\right]=0
$$

Pada regresi logistik, kedua persamaan tersebut tidak bersifat linier terhadap $\beta_{0}$ dan $\beta_{j}$. Oleh sebab itu, perlu metode khusus dalam penyelesaiannya. Penyelesaian tersebut biasanya menggunakan iterasi yang telah diprogram dalam software untuk pengolahan regresi logistik (Hosmer \& Lemeshow, 2000).

\section{Pengujian signifikansi parameter secara simultan}

Setelah didapatkan hasil pendugaan parameter, maka akan dilakukan pengujian signifikansi parameter dari hasil tersebut secara simultan (bersama-sama). Uji simultan digunakan untuk mengetahui apakah variabel penjelas dalam model secara bersama-sama berpengaruh signifikan terhadap keputusan lansia untuk bekerja. Pada uji simultan digunakan likelihood ratio test. Hipotesis yang diuji pada uji simultan adalah sebagai berikut:

$H_{0}: \beta_{1}=\beta_{2}=\beta_{3}=\cdots=\beta_{9}=0$ (tidak ada variabel penjelas yang berpengaruh secara signifikan terhadap keputusan lansia memilih untuk bekerja)

$H_{1}$ : Minimal ada satu $\beta_{j} \neq 0$ (terdapat minimal satu variabel penjelas yang berpengaruh secara signifikan terhadap keputusan lansia memilih untuk bekerja) dengan $j=1,2, \ldots, 9$ 
Statistik uji

$$
G=-2 \ln \left(\frac{\text { likelihood tanpa variabel prediktor }}{\text { likelihood dengan variabel prediktor }}\right)
$$

Berdasarkan hasil penghitungan nilai $\mathrm{G}$ dari uji rasio likelihood, keputusan akan Tolak $H_{0}$ jika $G>\chi_{(0,05 ; 9)}^{2}$ atau $p$-value $<0,05$ dan dapat diambil kesimpulan dengan tingkat signifikansi lima persen terdapat cukup bukti bahwa ada minimal satu variabel penjelas yang berpengaruh secara signifikan terhadap keputusan lansia memilih untuk bekerja.

\section{Pengujian signifikansi parameter secara parsial}

Setelah didapatkan keputusan Tolak $H_{0}$ pada uji simultan, maka selanjutnya dilakukan pengujian signifikansi parameter secara parsial yang digunakan untuk mengetahui variabel penjelas apa saja yang berpengaruh secara signifikan terhadap keputusan lansia yang memilih untuk bekerja. Uji parsial menggunakan uji Wald. Hipotesis yang diuji pada uji parsial adalah sebagai berikut:

$H_{0}: \beta_{j}=0$ (variabel penjelas ke-j tidak berpengaruh secara signifikan terhadap keputusan lansia untuk bekerja)

$H_{0}: \beta_{j} \neq 0$ (variabel penjelas ke-j berpengaruh secara signifikan terhadap keputusan lansia untuk bekerja)

dengan $j=1,2, \ldots, 9$

Statistik uji:

$$
W=\left[\frac{\widehat{\beta_{J}}}{\operatorname{se}\left(\widehat{\left.\beta_{J}\right)}\right.}\right]^{2}
$$

Berdasarkan hasil penghitungan nilai $W$ dari uji Wald, keputusan akan Tolak $H_{0}$ jika $W>\chi_{(0,05 ; 1)}^{2}$ atau $p-$ value $<0,05$.

\section{Analisis kurva Receiver Operating Characteristic (ROC)}

Kurva ROC dalam penelitian ini digunakan untuk melakukan pengujian kesesuaian model bersama dengan tabel klasifikasi. Tabel klasifikasi adalah hasil klasifikasi silang antara variabel dependen dengan variabel dikotomi yang nilainya diturunkan dari estimasi peluang pada model logistik (Hosmer \& Lemeshow, 2000). Dalam memperoleh variabel dikotomi turunan, maka harus menentukan nilai cut-point (c) terlebih dahulu. Nilai c nantinya akan dibandingkan dengan setiap estimasi peluang model logistik dan biasanya dalam klasifikasi tabel pada umumnya menggunakan nilai c sebesar 0,5. Nilai c tersebut dapat diubah-ubah sesuai dengan nilai titik potong antara sensitivity dan specificity pada setiap titik potong (cut-off) yang mungkin. Pada penelitian ini akan digunakan nilai c sebesar 0,5. Apabila nilai estimasi peluang kurang dari 0,5 maka nilai variabel turunan adalah 0 , sebaliknya jika nilai estimasi peluang lebih dari sama dengan 0,5 maka nilai variabel turunan adalah 1 (Hosmer \& Lemeshow, 2000).

Apabila model telah akurat dalam memprediksi keanggotaan kelompok menurut beberapa kriteria yang ada, maka dapat dikatakan bahwa model yang dihasilkan sudah cocok (fit). Pada Tabel 3 dapat dilihat bahwa akan didapatkan hasil nilai persentase total ketepatan klasifikasi, sensitivity, dan specificity. Jika nilai persentasenya semakin besar, maka menandakan model semakin baik. Sensitivity 
menunjukkan persentase lansia bekerja diprediksi secara benar kembali ke dalam kelompok lansia bekerja. Specificity menunjukkan persentase lansia tidak bekerja diprediksi secara benar kembali ke dalam kelompok lansia tidak bekerja.

Tabel 3: Tabel klasifikasi.

\begin{tabular}{cccc}
\hline \multirow{2}{*}{ Observasi } & \multicolumn{2}{c}{ Prediksi } & \multirow{2}{*}{ Total } \\
\cline { 2 - 3 } & $\mathrm{Y}=1$ & $\mathrm{Y}=0$ & \\
\hline$(1)$ & $(2)$ & $(3)$ & $(4)$ \\
$\mathrm{Y}=1$ & $\mathrm{TP}$ & $\mathrm{FN}$ & $\mathrm{TP}+\mathrm{FN}$ \\
$\mathrm{Y}=0$ & $\mathrm{FP}$ & $\mathrm{TN}$ & $\mathrm{FP}+\mathrm{TN}$ \\
Total & TP+FP & $\mathrm{FN}+\mathrm{TN}$ & \\
Persentase total ketepatan klasifikasi & $\%$ \\
\hline
\end{tabular}

Kurva ROC merupakan hasil plot antara true signal (sensitivity) dan false signal (1-specificity) pada keseluruhan rentang titik cut-off yang mungkin. Rentang dari luas area di bawah kurva ROC adalah nol sampai satu. Luas area di bawah kurva mampu mengukur seberapa besar kemampuan model untuk mendiskriminasi observasi yang mengalami kejadian sukses dan tidak mengalami kejadian sukses. Biasanya kurva ROC berbentuk cekung yang menghubungkan antara titik $(0,0)$ dan titik $(1,1)$.

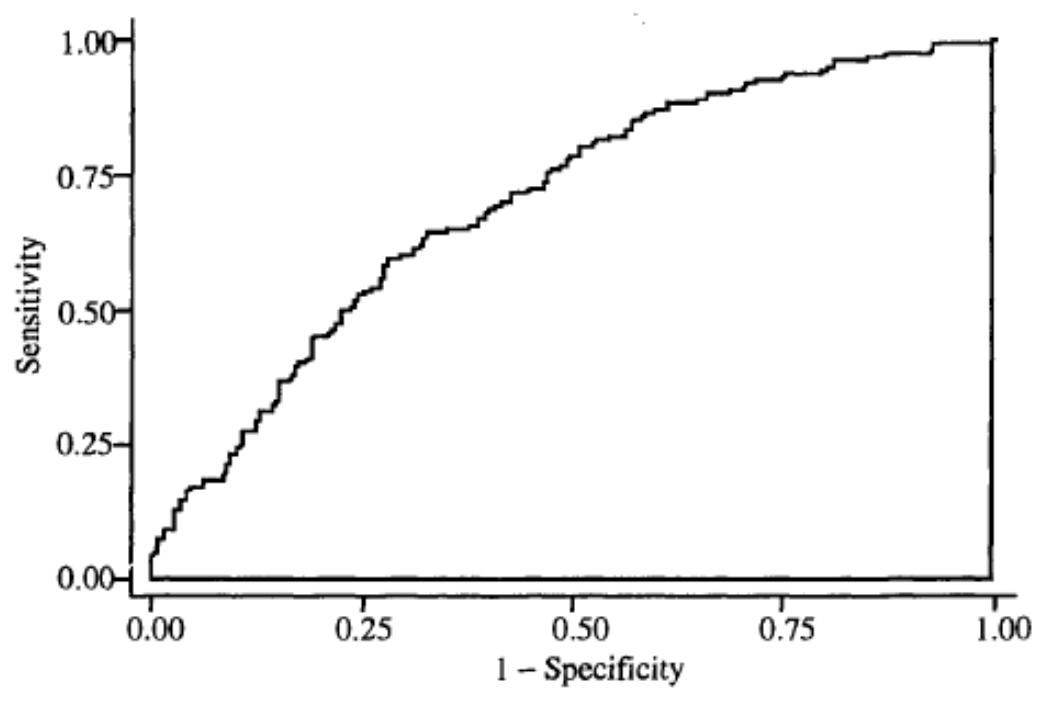

Sumber: (Hosmer \& Lemeshow, 2000)

Gambar 1: Kurva ROC.

Dalam penginterpretasiannya, dapat kita lihat pada Gambar 1. Semakin tinggi area yang berada di bawah kurva maka semakin baik model tersebut dalam memprediksi. Kurva ROC juga lebih informatif jika dibandingkan dengan tabel klasifikasi, karena kurva ROC memberikan hasil prediksi seluruh cut-off yang mungkin terjadi (Agresti, 2000). Kurva yang terbentuk dari titik-titik atas semua kemungkinan cut-off tersebut disebut sebagai kurva ROC.

Jika luas area di bawah kurva ROC yang dihasilkan $<0,5$, maka model statistik yang dievaluasi memiliki tingkat keakuratan yang sangat rendah dan mengindikasikan 
bahwa model tersebut sangat buruk jika digunakan (Zou et al., 2015). Sedangkan menurut Hosmer \& Lemeshow (2000) mengatakan bahwa model klasifikasi dapat diterima jika luas area di bawah kurva ROC $\geq 0,7$.

Kleinbaum \& Klein (2010) dalam menghitung luas area di bawah kurva ROC menggunakan rumus sebagai berikut:

$$
\text { luas area dibawah kurva } R O C=\frac{w+0,5 z}{n_{p}}
$$

Keterangan:

$w$ : jumlah $\hat{P}\left(X_{\text {case }}\right)>\hat{P}\left(X_{\text {noncase }}\right)$

$z:$ jumlah $\hat{P}\left(X_{\text {case }}\right)=\hat{P}\left(X_{\text {noncase }}\right)$

$n_{p}$ : jumlah semua pasangan $\left(n_{\text {case }} \times n_{\text {noncase }}\right)$

$\hat{P}$ : peluang hasil estimasi untuk setiap observasi

Dari hasil perhitungan tersebut, Kleinbaum \& Klein (2010) mengkategorikan hasil luas area di bawah kurva ROC sebagai berikut:

$0,9<$ luas area di bawah kurva ROC $\leq 1,0=$ Excellent discrimination

$0,8<$ luas area di bawah kurva ROC $\leq 0,9=$ Good discrimination

$0,7<$ luas area di bawah kurva ROC $\leq 0,8=$ Fair discrimination

$0,6<$ luas area di bawah kurva ROC $\leq 0,7=$ Poor discrimination

$0,5<$ luas area di bawah kurva ROC $\leq 0,6=$ Failed discrimination

5. Interpretasi rasio kecenderungan (odds ratio)

Odds ratio (rasio kecenderungan) digunakan untuk mengetahui tingkat risiko perbandingan antara dua kejadian yang masuk ke dalam sukses atau gagal. Pada penelitian ini, rasio kecenderungan digunakan untuk membandingkan kecenderungan lansia bekerja dibandingkan lansia tidak bekerja berdasarkan variabel penjelas yang sudah ada. Nilai odds ratio didapatkan dengan mengeksponensialkan koefisien $\widehat{\beta}_{\mathrm{J}}$.

\section{Hasil dan Pembahasan}

\subsection{Karakteristik Lansia dan Lansia Bekerja di Kawasan Timur Indonesia}

Penduduk lanjut usia di Indonesia pada tahun 2018 yaitu sebesar 9,27 persen dari total seluruh penduduk (BPS, 2018b). Untuk melihat persebaran penduduk lansia di Kawasan Timur Indonesia, dapat dilihat pada Gambar 2. Terdapat dua provinsi dengan persentase penduduk lansia berada di atas persentase nasional $(9,27$ persen), yaitu Provinsi Sulawesi Utara sebesar 10,73 persen dan provinsi Sulawesi Selatan sebesar 9,32 persen. Sedangkan persentase penduduk lansia terendah di KTI adalah Provinsi Papua Barat (4,55 persen) dan Provinsi Papua (3,34 persen). 


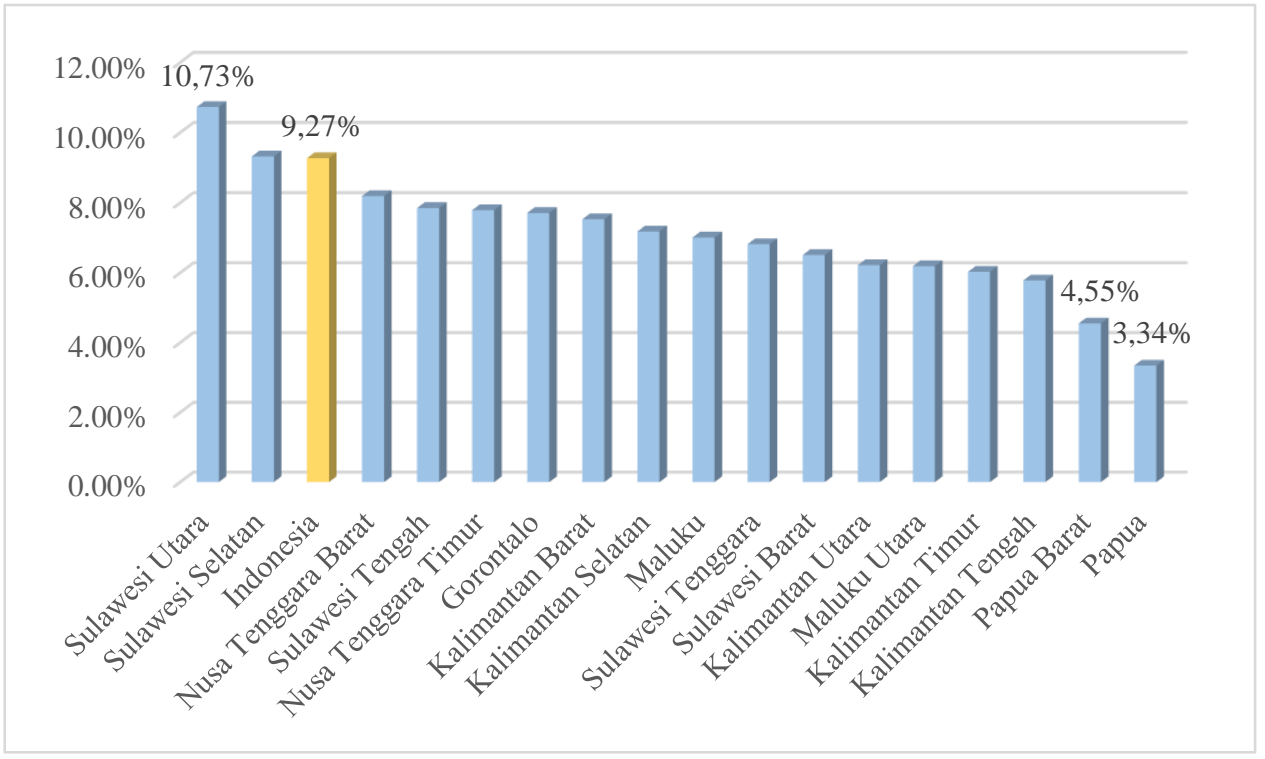

Sumber: Susenas Kor Maret 2018, diolah.

Gambar 2: Persentase Lansia di Kawasan Timur Indonesia Tahun 2018.

Provinsi Sulawesi Utara termasuk ke dalam kategori provinsi yang memasuki struktur umur penduduk tua. Suatu daerah dikatakan memiliki struktur umur penduduk tua jika persentase penduduk lansia terhadap seluruh penduduk di wilayah tersebut melebihi angka tujuh persen (BPS, 2018b). Jika dilihat berdasarkan Angka Harapan Hidup (AHH) Provinsi Sulawesi Utara yaitu sebesar 71,26 tahun, sehingga dapat disimpulkan bahwa rata-rata jumlah tahun yang akan dijalani oleh seseorang sejak orang tersebut lahir adalah 71,26 tahun. Angka tersebut juga termasuk ke dalam kategori lebih tinggi dari rata-rata nasionalnya (71,20 tahun) dibandingkan dengan provinsi-provinsi lainnya yang berada di Kawasan Timur Indonesia.

Pada Lampiran 1 dapat diketahui karakteristik lansia di Kawasan Timur Indonesia. Persentase lansia yang bekerja di KTI sebesar 51,11 persen sedangkan lansia yang tidak bekerja sebesar 48,89 persen. Hal ini mengindikasikan bahwa lansia di KTI masih banyak yang bekerja karena 1 dari 2 lansia di KTI bekerja. Angka tersebut mengindikasikan bahwa tingkat kesejahteraan lansia di KTI masih rendah dan mengharuskan lansia tetap bekerja. Lansia di KTI masih banyak yang bertempat tinggal di perdesaan yaitu sebesar 69,99 persen sedangkan sisanya sebesar 30,01 persen bertempat tinggal di perkotaan. Berdasarkan jenis kelamin, lansia perempuan lebih besar dibandingkan lansia laki-laki. Sebanyak 52 persen lansia di KTI berjenis kelamin perempuan sedangkan sisanya berjenis kelamin lakilaki. BPS mengelompokkan usia lansia menjadi tiga kategori, yakni lansia muda, lansia madya, dan lansia tua. Lansia di KTI lebih didominasi oleh golongan lansia muda sebesar 64,05 persen. Selanjutnya lansia madya yaitu sebesar 27,37 persen dan yang terakhir lansia tua yaitu sebesar 8,58 persen saja. Dengan kata lain lansia di KTI didominasi oleh lansia muda atau masih banyak lansia yang produktif untuk melakukan kegiatan, salah satunya adalah bekerja.

Jika dilihat dari pendidikan tertinggi yang ditamatkan, persentase yang paling besar adalah lansia dengan tingkat pendidikan terakhir yang ditamatkan SD ke 
bawah yaitu sebesar 61,65 persen sedangkan sebesar 38,35 persen lansia di Kawasan Timur Indonesia mempunyai tingkat pendidikan SMP ke atas. Sedangkan lansia di Kawasan Timur Indonesia yang berstatus sebagai Kepala Rumah Tangga (KRT) lebih besar yaitu sebesar 59,74 persen dan 40,26 persen lainnya merupakan lansia yang berstatus selain KRT dalam keluarganya.

Berdasarkan status perkawinan lansia, persentase lansia yang kawin di Kawasan Timur Indonesia lebih besar dibandingkan dengan persentase lansia yang tidak kawin. Lansia yang kawin sebesar 60,16 persen dan 39,84 persen lansia tidak kawin. Lansia yang mempunyai keluhan kesehatan yaitu sebesar 51,86 persen sedangkan persentase lansia yang tidak punya keluhan kesehatan yaitu sebesar 48,14 persen. Jika dilihat dari kepemilikan jaminan kesehatan, lansia yang mempunyai jaminan kesehatan di Kawasan Timur Indonesia sebesar 69,62 persen sedangkan lansia yang tidak punya jaminan kesehatan sebesar 30,38 persen.

Jika dilihat pada Lampiran 2 dapat diketahui persentase lansia bekerja di Kawasan Timur Indonesia lebih dominan tinggal di perdesaan yaitu sebesar 56 persen sedangkan yang tinggal di perkotaan sebesar 36,69 persen. Persentase lansia bekerja yang berjenis kelamin laki-laki (67,86 persen) lebih besar daripada berjenis kelamin perempuan (35,64 persen). Berdasarkan faktor usia, persentase lansia bekerja yang digolongkan ke dalam lansia muda sebesar 60,61 persen, lansia bekerja yang digolongkan ke dalam lansia madya sebesar 39,14 persen, dan yang terakhir adalah lansia tua sebesar 18,36 persen. Persentase lansia bekerja yang mempunyai pendidikan SD ke bawah (54,40 persen) lebih besar daripada SMP ke atas (45,81 persen). Lansia bekerja yang di keluarganya berperan sebagai Kepala Rumah Tangga (KRT) juga lebih besar, yakni mencapai 64,59 persen sedangkan yang berstatus sebagai selain KRT sebesar 31,10 persen. Jika dilihat dari status perkawinannya, lansia bekerja yang kawin sebesar 61,44 persen dan lansia bekerja yang tidak kawin sebesar 35,50 persen. Lansia bekerja yang mempunyai keluhan kesehatan sebesar 48,63 persen, sementara lansia bekerja yang tidak mempunyai keluhan kesehatan sebesar 53,78 persen. Persentase lansia bekerja yang mempunyai jaminan kesehatan sebesar 50,54 persen. Persentase tersebut lebih kecil dibandingkan dengan lansia bekerja yang tidak mempunyai jaminan kesehatan yaitu sebesar 52,40 persen.

\subsection{Hasil dan Pembahasan Analisis Inferensia}

\section{a. Uji Simultan}

Berdasarkan hasil uji simultan diperoleh nilai chi-square sebesar 9.141,307 dan nilai ini lebih besar dari nilai kritis pada tabel chi square $(16,92)$ dengan nilai $p$-value $<0,05$, sehingga keputusan yang diambil adalah Tolak HO. Sehingga dapat diambil kesimpulan dengan tingkat signifikansi lima persen, terdapat cukup bukti untuk mengatakan bahwa minimal terdapat satu variabel penjelas yang berpengaruh terhadap keputusan lansia dalam menentukan bekerja.

\section{b. Uji Parsial}

Berikut adalah rangkuman output hasil pengolahan uji parsial pada seluruh variabel penjelas yang digunakan dalam penelitian ini: 
Tabel 4: Tabel Rangkuman Hasil Pengolahan Uji Parsial Regresi Logistik Biner.

\begin{tabular}{lrrrr}
\hline \multicolumn{1}{c}{ Variabel } & B & \multicolumn{1}{c}{ Wald } & P-value & Exp(B) \\
\hline Tempat Tinggal (Perdesaan) & 0,827 & 859,229 & 0,000 & 2,286 \\
Jenis Kelamin (Laki-laki) & 0,525 & 244,413 & 0,000 & 1,690 \\
Usia & & 1685,83 & 0,000 & \\
Usia (Lansia Muda) & 1,810 & 1072,3 & 0,000 & 6,111 \\
Usia (Lansia Madya) & 0,928 & 261,358 & 0,000 & 2,530 \\
Tingkat Pendidikan (SD ke bawah) & 0,343 & 170,524 & 0,000 & 1,410 \\
Status dalam Rumah Tangga & 1,267 & 1510,48 & 0,000 & 3,550 \\
Status Perkawinan (Kawin) & 0,728 & 607,006 & 0,000 & 2,071 \\
Keluhan Kesehatan (Tidak Punya) & 0,256 & 101,61 & 0,000 & 1,292 \\
Jaminan Kesehatan (Tidak Punya) & 0,208 & 55,099 & 0,000 & 1,231 \\
Constant & $-2,516$ & 1600,09 & 0,000 & 0,081 \\
\hline
\end{tabular}

Berdasarkan Tabel 4, maka keputusan yang diambil adalah Tolak $\mathrm{H} 0$ untuk semua variabel penjelas. Keputusan tersebut diambil karena nilai $p$-value $<0,05$. Sehingga dapat diambil kesimpulan untuk masing-masing variabel penjelas dengan tingkat signifikansi lima persen, terdapat cukup bukti untuk mengatakan bahwa variabel penjelas ke-j berpengaruh secara signifikan terhadap keputusan lansia untuk bekerja.

Dari hasil uji parsial tersebut, maka dapat dituliskan persamaan regresi logistik biner yang terbentuk adalah sebagai berikut:

$$
\begin{aligned}
\widehat{g(x)}=\ln \left(\frac{\widehat{\pi(x)}}{1-\overline{\pi(x)}}\right) \\
=-2,516+0,827 \text { TempatTing gal }(1)^{*}+0,525 \text { JenisKelamin }(1)^{*}+1,810 \operatorname{Umur}(1)^{*} \\
+0,928 \text { Umur }(2)^{*}+0,343 \text { Pendidikan }(1)^{*}+1,267 \operatorname{StatusKRT}(1)^{*} \\
+0,, 728 \text { StatusKawin }(1)^{*}+0,256 \text { KeluhanKesehatan }(1)^{*} \\
+0,208 \text { JaminanKesehatan }(1)^{*}
\end{aligned}
$$

keterangan: *) signifikan pada tingkat signifikansi 5 persen

\section{c. Analisis Kurva ROC}

Pada penelitian ini, kurva ROC digunakan untuk uji kesesuaian model yang digunakan, selain analisis dengan tabel klasifikasi. Pada Tabel 5 dapat kita ketahui persentase total ketepatan klasifikasinya sebesar 70,8 persen. Sehingga secara keseluruhan, model tersebut dapat mengklasifikasian seluruh observasi secara benar sebesar 70,8 persen dan sisanya diklasifikasikan secara salah. Dari hasil tersebut juga dapat dilihat nilai dari sensitivity dan specificity. Sensitivity dari model tersebut sebesar 72,4 persen. Sensitivity menunjukkan 72,4 persen lansia bekerja diprediksi secara benar kembali ke dalam kelompok lansia bekerja. Sedangkan nilai specificity sebesar 69,2 persen. Hal ini berarti, 69,2 persen lansia tidak bekerja diprediksi secara benar kembali ke dalam kelompok lansia tidak bekerja. 
Tabel 5: Tabel Hasil Klasifikasi Regresi Logistik Biner.

\begin{tabular}{|c|c|c|c|c|}
\hline & \multicolumn{2}{|c|}{$\begin{array}{l}\text { Keputusan } \\
\text { Bekerja }\end{array}$} & \multirow{2}{*}{$\begin{array}{c}\text { Persentase } \\
\text { Total } \\
\text { Ketepatan } \\
\text { Klasifikasi }\end{array}$} \\
\hline & & Bekerja & $\begin{array}{l}\text { Tidak } \\
\text { Bekerja }\end{array}$ & \\
\hline \multicolumn{2}{|l|}{ (1) } & (2) & (3) & (4) \\
\hline \multirow{2}{*}{$\begin{array}{c}\text { Keputusan } \\
\text { Bekerja }\end{array}$} & Bekerja & 12452 & 4738 & $72,4 \%$ \\
\hline & $\begin{array}{l}\text { Tidak } \\
\text { Bekerja }\end{array}$ & 5073 & 11373 & $69,2 \%$ \\
\hline & & & & $70,8 \%$ \\
\hline
\end{tabular}

Selain melihat dari tabel klasifikasi, kesesuaian model juga dapat dilakukan melalui luasan area di bawah kurva ROC. Jika dilihat dari hasil pengolahan luas area di bawah kurva ROC pada Gambar 3, menandakan model sudah sesuai karena kurva yang dihasilkan mendekati angka satu. Hal ini juga didukung dengan luas area di bawah kurva ROC yaitu sebesar 0,786. Sesuai dengan teori Hosmer dan Lemeshow (2000) yang berpendapat bahwa klasifikasi model dapat diterima jika luas area di bawah kurva $R O C \geq 0,7$. Maka dapat disimpulkan model tersebut cukup baik untuk menjelaskan determinan keputusan lansia untuk bekerja dengan kategori fair discrimination.

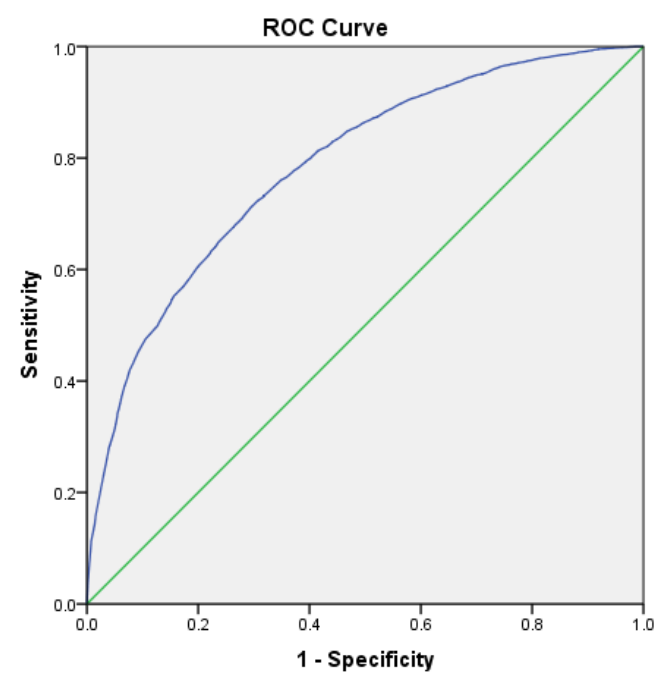

Diagonal segments are produced by ties.

Gambar 3: Kurva ROC Analisis Regresi Logistik Biner Lansia Bekerja.

Dapat dilihat juga interval pada Tabel 6 , kepercayaan dari model tersebut yaitu antara 0,781 dan 0,791. Dengan rentang yang tidak terlalu lebar maka hal ini menandakan bahwa model tersebut sudah presisi untuk menjelaskan hubungan antara variabel penjelas dengan keputusan lansia untuk bekerja. 
Tabel 6: Tabel Hasil Luas Area Kurva ROC Regresi Logistik Biner.

\begin{tabular}{ccc}
\hline Area & \multicolumn{2}{c}{ Asymptotic 95\% Confidence Interval } \\
Lower Bound & Upper Bound \\
\hline 0,786 & 0,781 & 0,791 \\
\hline
\end{tabular}

\section{d. Interpretasi Odds Ratio}

Tempat Tinggal

Klasifikasi tempat tinggal lansia yang terdiri dari dua kategori yaitu perkotaan dan perdesaan memiliki pengaruh yang signifikan terhadap keputusan lansia untuk bekerja. Lansia yang tinggal di perdesaan memiliki kecenderungan lebih besar sebesar 2,286 kali untuk bekerja dibandingkan lansia yang tinggal di perkotaan jika semua variabel lain konstan. Hal ini sejalan dengan pendapat Affandi (2009) yang mengemukakan bahwa lansia yang tinggal di perdesaan lebih banyak yang bekerja dibandingkan lansia yang tinggal di perkotaan. Penyebab banyaknya lansia di perdesaan yang masih bekerja karena peluang untuk bekerja yang lebih besar di daerah perdesaan dibandingkan perkotaan khusunya dalam sektor pertanian.

\section{Jenis Kelamin}

Lansia laki-laki memiliki kecenderungan lebih besar sebesar 1,690 kali untuk bekerja dibandingkan lansia perempuan apabila semua variabel lain konstan. Hasil ini sesuai dengan penemuan Ling dan Chi (2008) yang menyatakan bahwa lansia laki-laki berpeluang lebih besar untuk bekerja dibandingkan dengan lansia perempuan. Kejadian tersebut dapat disebabkan banyaknya lansia laki-laki yang berperan sebagai kepala keluarga sekaligus kepala rumah tangga di dalam keluarganya. Kepala rumah tangga adalah anggota yang memiliki peran paling penting di dalam keluarganya, terutama dalam memenuhi kebutuhan keluarganya. Selain itu, alasan lainnya adalah berkaitan dengan tradisi bahwa perempuan seharusnya tetap berada di rumah dan mengurus rumah tangga.

\section{Usia}

Kategorisasi usia lansia juga berpengaruh secara signifikan terhadap keputusan lansia untuk bekerja. Lansia muda (60-69 tahun) memiliki kecenderungan sebesar 6,111 kali untuk bekerja dibandingkan lansia tua (80+ tahun), sedangkan lansia madya (70-79 tahun) memiliki kecenderungan yang lebih kecil yakni 2,530 kali untuk bekerja dibandingkan lansia tua ( $80+$ tahun) dengan asumsi semua variabel lain konstan. Pang et al. (2004) menemukan hasil yang serupa yaitu seiring dengan bertambahnya usia, maka kecenderungan lansia untuk bekerja semakin kecil karena semakin tua usia lansia, semakin lemah kondisi fisik lansia untuk bekerja. 


\section{Pendidikan}

Pendidikan terakhir yang ditamatkan oleh lansia juga berpengaruh secara signifikan terhadap keputusan lansia untuk bekerja. Lansia dengan pendidikan tertinggi SD/sederajat ke bawah memiliki kecenderungan bekerja sebesar 1,410 kali dibandingkan lansia yang berpendidikan SMP/sederajat ke atas ketika semua variabel lain konstan. McNair dalam Phillipson \& Smith (2005) menjelaskan tingkat pendidikan lansia berpengaruh terhadap keputusan seseorang untuk melanjutkan bekerja setelah memasuki masa pensiun. Dimana lansia dengan pendidikan yang rendah cenderung lebih banyak yang masih bekerja. Alasan lansia dengan tingkat pendidikan tinggi cenderung tidak bekerja adalah ketika masih muda, lansia tersebut sanggup mendapatkan pekerjaan yang lebih baik sehingga hasil kerja keras di masa muda dapat dinikmati di masa tua dan alasan lainnya adalah masih tersedianya lapangan usaha sektor pertanian maupun sektor informal yang mampu menampung lansia dengan pendidikan rendah.

\section{Status dalam Rumah Tangga}

Lansia yang berstatus sebagai kepala rumah tangga memiliki kecenderungan 3,550 kali untuk bekerja dibandingkan lansia bukan sebagai kepala rumah tangga. Sejalan dengan pendapat Sumarsono (2015) yang menjelaskan bahwa penduduk lansia yang berstatus sebagai kepala rumah tangga akan memiliki kecenderungan untuk bekerja jika dibandingkan dengan anggota keluarga lainnya karena dilandaskan atas rasa tanggung jawab sebagai kepala keluarga dalam memenuhi kebutuhan keluarganya.

\section{Status perkawinan}

Lansia yang berstatus kawin memiliki kecenderungan sebesar 2,071 kali untuk bekerja dibandingkan lansia yang tidak kawin (belum kawin, cerai mati dan cerai hidup) dengan anggapan semua variabel lain konstan. Sejalan dengan hal tersebut, Rosyada \& Trihandini (2013) berpendapat bahwa lansia yang berstatus kawin akan memiliki keingininan untuk bekerja lebih tinggi karena lansia yang berstatus kawin memiliki tanggung jawab yang lebih besar untuk menghidupi keluarganya sehingga lebih cenderung untuk tetap bekerja.

\section{Keluhan kesehatan}

Lansia yang tidak mengalami keluhan kesehatan memiliki kecenderungan sebesar 1,292 kali untuk bekerja dibandingkan lansia yang mengalami keluhan kesehatan jika semua variabel lain konstan. Rosyada dan Trihandini (2013) juga menemukan hal yang serupa yaitu bahwa lansia dengan kesehatan baik akan memiliki keinginan untuk bekerja lebih tinggi dibandingkan dengan lansia yang mempunyai kesehatan tidak baik.

\section{Jaminan kesehatan}

Lansia yang tidak punya jaminan kesehatan memiliki kecenderungan untuk bekerja sebesar 1,231 kali dibandingkan lansia yang mempunyai jaminan kesehatan dengan asumsi semua variabel lain konstan. Sejalan dengan penemuan Ling \& Chi (2008) bahwa lansia yang memiliki jaminan kesehatan akan berhubungan negatif 
terhadap lansia bekerja. Lansia yang telah mendapatkan manfaat jaminan kesehatan memiliki jaminan rasa aman akan perlindungan kesehatan di masa tua sehingga lansia yang memiliki jaminan kesehatan cenderung memilih untuk tidak bekerja.

\section{Kesimpulan}

Dari penelitian yang sudah dilakukan tersebut, maka dapat diambil kesimpulan sebagai berikut. Di Kawasan Timur Indonesia, sebagian besar lansia mempunyai karakteristik memilih untuk tetap bekerja, tinggal di perdesaan, berjenis kelamin perempuan, termasuk ke dalam kategori lansia muda (60-69 tahun), mempunyai tingkat pendidikan tertinggi SD ke bawah, berperan sebagai Kepala Rumah Tangga (KRT) dalam keluarganya, berstatus kawin, mempunyai keluhan kesehatan, dan tidak mempunyai jaminan kesehatan. Tempat tinggal, jenis kelamin, usia, pendidikan, status dalam keluarga, status perkawinan, keluhan kesehatan, dan jaminan kesehatan secara signifikan memengaruhi keputusan lansia untuk bekerja.

Berdasarkan analisis kurva ROC, maka model logit yang terbentuk dapat disimpulkan tergolong ke dalam kategori Fair discrimination. Sehingga dapat dikatakan bahwa model logit sudah sesuai (fit) untuk mengestimasi parameter. Lansia yang mempunyai karakteristik bertempat tinggal di perdesaan, berjenis kelamin lakilaki, tergolong ke dalam lansia muda (60-69 tahun), mempunyai tingkat pendidikan tertinggi SD ke bawah, berstatus sebagai Kepala Rumah Tangga (KRT) dalam keluarganya, berstatus kawin, tidak mempunyai keluhan kesehatan, dan tidak mempunyai jaminan kesehatan akan memiliki kecenderungan yang lebih besar untuk memutuskan bekerja.

\section{Daftar Pustaka}

Affandi, M. (2009). Faktor-faktor yang memengaruhi penduduk lanjut usia memilih untuk bekerja. Journal of Indonesian Applied Economics, 3: 99-110. https://doi.org/10.21776/ub.jiae.2009.003.02.6

Agresti, A. (2000). Categorical data analysis (2nd ed). New York (US): John Wiley \& Sons.

Azen, R., \& Walker, C. M. (2011). Categorical data analysis for the behavioral and social sciences. https://doi.org/10.4324/9780203843611

[BPS] Badan Pusat Statistik. (2015). Statistik penduduk lanjut usia 2014. Jakarta (ID): Badan Pusat Statistik.

[BPS] Badan Pusat Statistik. (2016). Statistik penduduk lanjut usia 2015. Jakarta (ID): Badan Pusat Statistik.

[BPS] Badan Pusat Statistik. (2017). Statistik penduduk lanjut usia 2016. Jakarta (ID): Badan Pusat Statistik. 
[BPS] Badan Pusat Statistik. (2018a). Statistik penduduk lanjut usia 2017. Jakarta (ID): Badan Pusat Statistik.

[BPS] Badan Pusat Statistik. (2018b). Statistik penduduk lanjut usia 2018. Jakarta (ID): Badan Pusat Statistik.

Hosmer, D. W., \& Lemeshow, S. (2000). Applied Logistic Regression. New York (US): John Wiley \& Sons.

Kleinbaum, D. G., \& Klein, M. (2010). Logistic regression: A self learning text (3rd ed). New York (US): Springer-Verlag.

Ling, D. C., \& Chi, I. (2008). Determinants of work among older adults in urban China. Australasian Journal on Ageing, 27(3): 126-133.

Pang, L., De Brauw, A., \& Rozelle, S. (2004). Working until you drop: The elderly of rural China. The China Journal, (52): 73-94.

[Pemerintah RI]. (1998). Undang-Undang Republik Indonesia Nomor 13 Tahun 1998 Tentang Kesejahteraan Lanjut Usia.

Phillipson, C., \& Smith, A. (2005). Extending working life: A review of the research literature (Vol. 299). CDS.

Reddy, A. B. (2016). Labour force participation of elderly in India: patterns and determinants. International Journal of Social Economics, 43(5): 502-516.

Rosyada, A., \& Trihandini, I. (2013). Determinan komplikasi kronik diabetes melitus pada lanjut usia. Kesmas: National Public Health Journal, 7(9): 395-402.

Sumarsono, F. S. (2015). Analisis partisipasi kerja penduduk lanjut usia di indonesia. Jurnal IImiah Mahasiswa FEB, 4(1): 1-19.

[WHO] World Health Organization. (2002). Proposed working definition of an older person in Africa for the MDS Project. World Health Organization.

Zou, K. H., O'Malley, J., \& Mauri, L. (2015). Receiver-operating characteristic analysis for evaluating diagnostic tests and predictive models. Circulation, 115(5): 654-657. 


\section{Lampiran 1. Karakteristik lansia di Kawasan Timur Indonesia.}

Tempat Tinggal

- Perkotaan

Perdesaan

$69,99 \%$
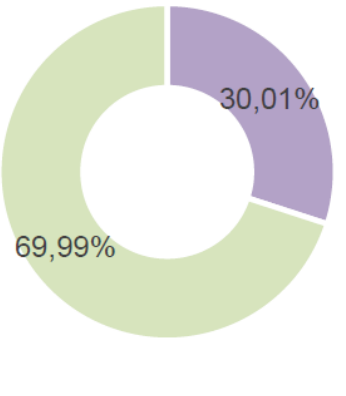

Jenis Kelamin

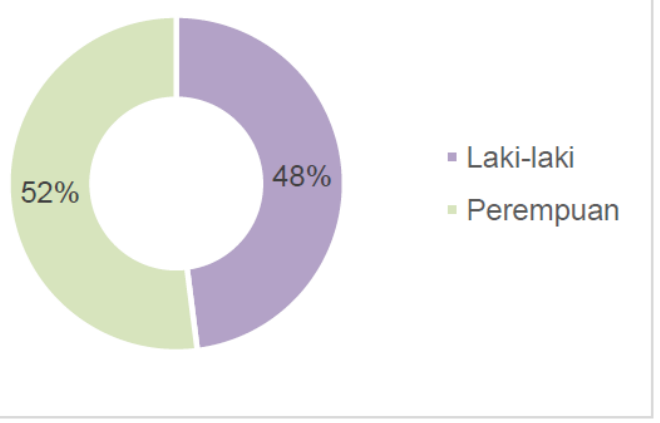

Usia

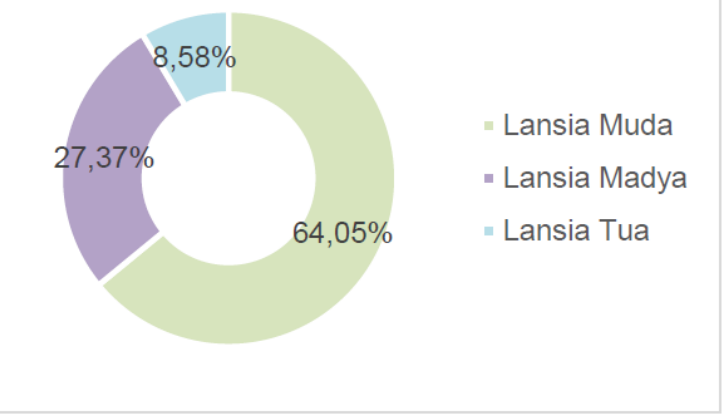

Tingkat Pendidikan

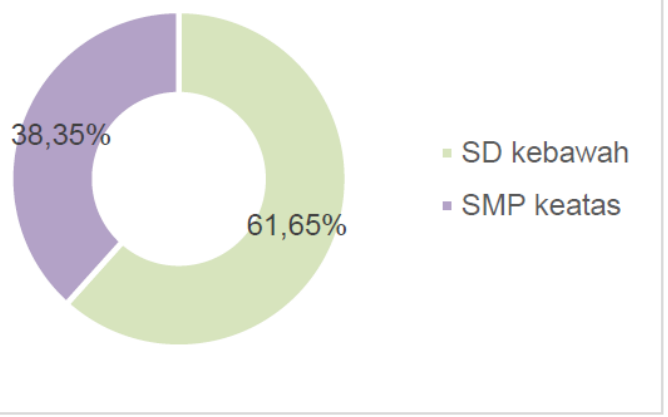

Status dalam Rumah Tangga

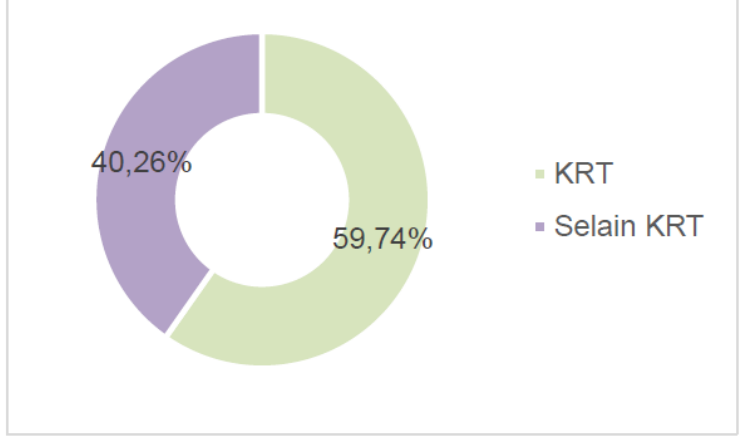

Status Perkawinan

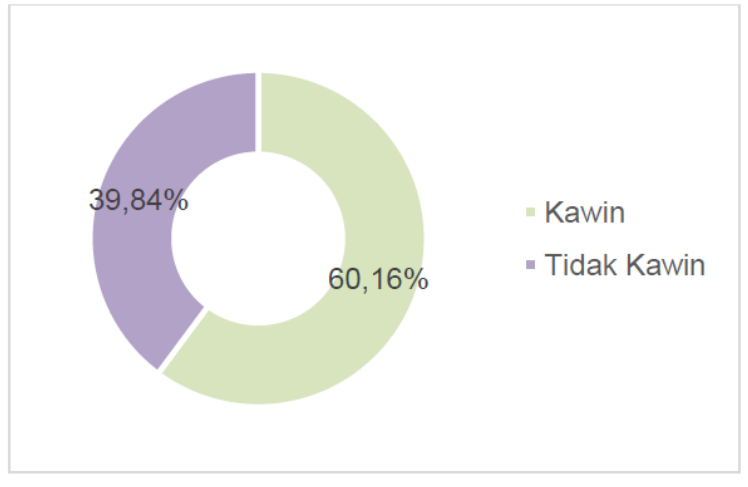

Keluhan Kesehatan

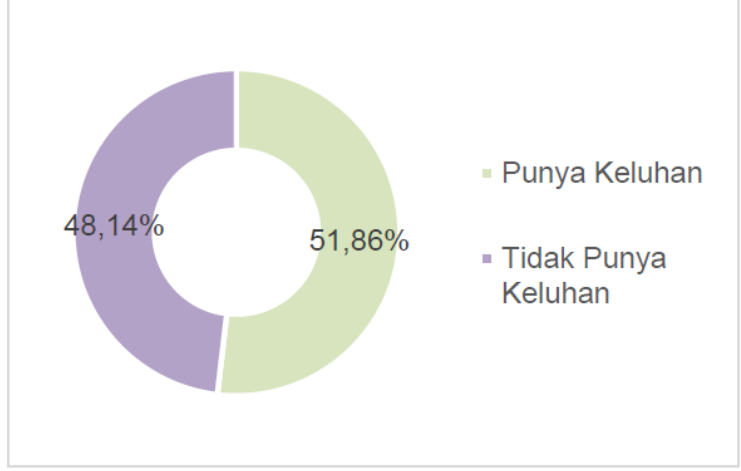

Jaminan Kesehatan

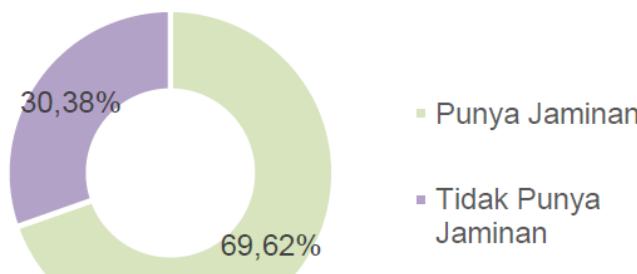




\section{Lampiran 2. Persentase lansia bekerja di Kawasan Timur Indonesia}

\section{Tempat Tinggal}

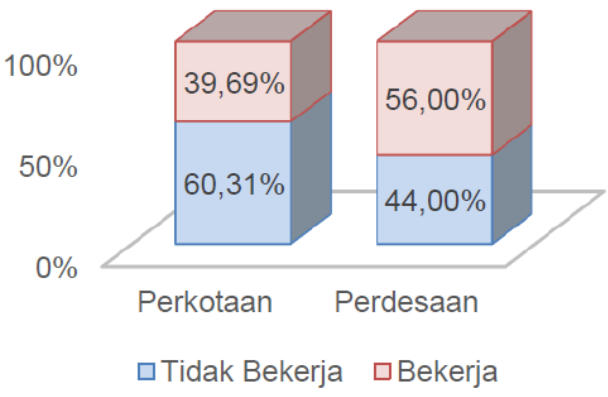

Jenis Kelamin

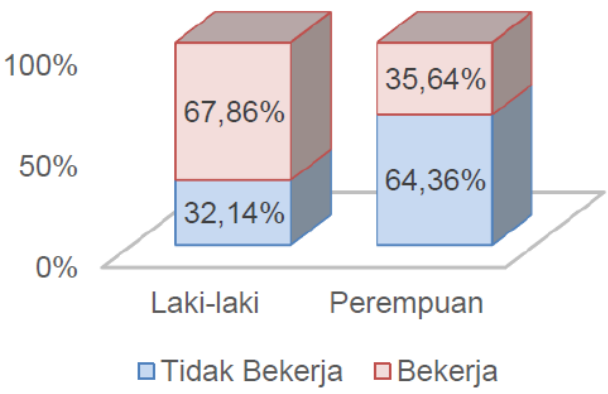

Usia

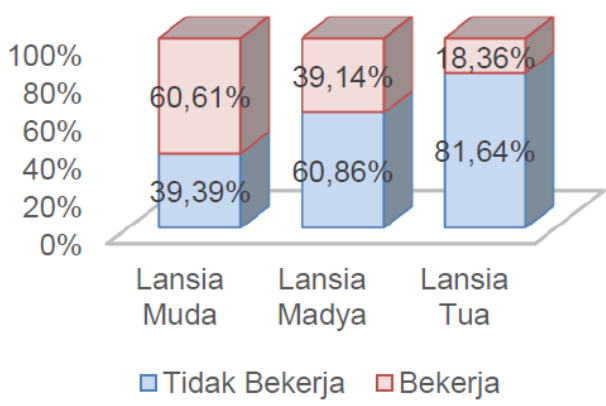

Tingkat Pendidikan

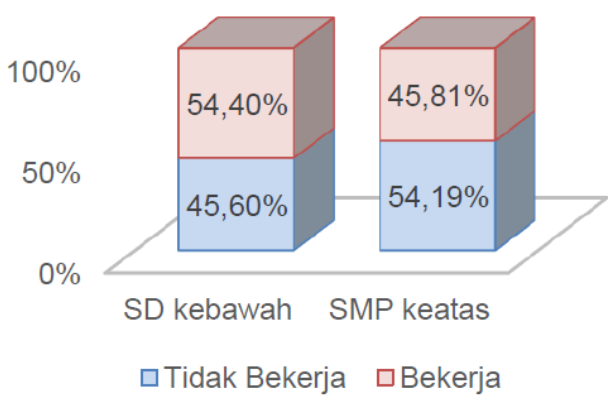

Status dalam Rumah Tangga

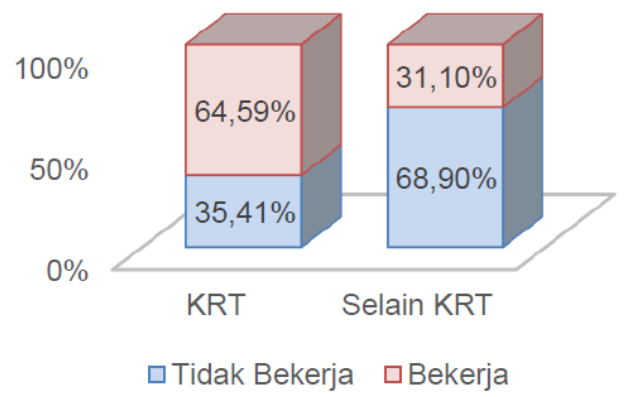

Status Perkawinan

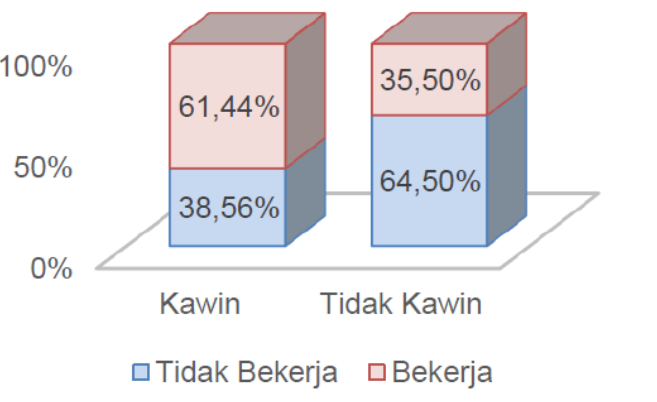

Keluhan Kesehatan

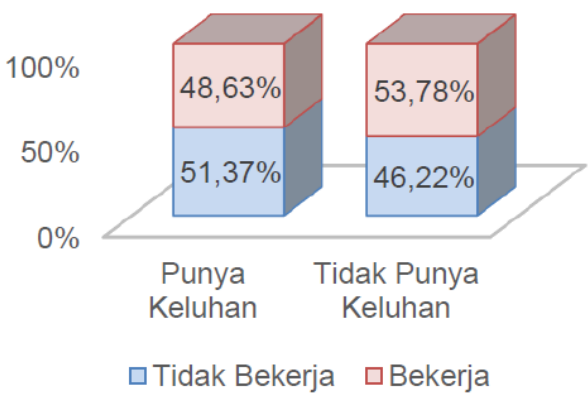

Jaminan Kesehatan

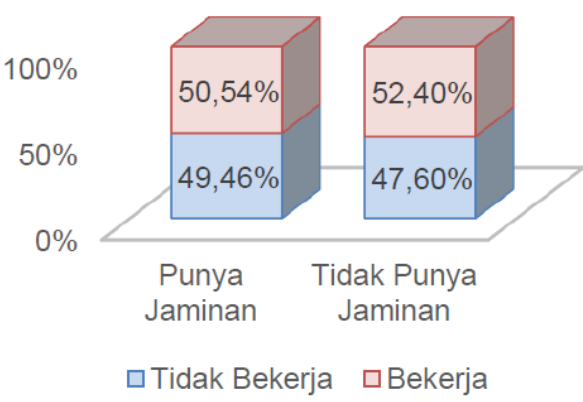

